JURNAL NOMINAL / VOLUME VII NOMOR 2 / TAHUN 2018

\title{
PENGARUH INFLASI, NILAI TUKAR RUPIAH/DOLAR AS, TINGKAT SUKU BUNGA BI, DER, ROA, CR DAN NPM TERHADAP RETURN SAHAM
}

\section{THE INFLUENCE OF INFLATION, EXCHANGE RATE OF RUPIAH/US DOLLAR, INTEREST RATE OF BI, DER, ROA, CR, AND NPM TOWARD THE STOCK RETURN}

\author{
Sri Haryani \\ Prodi Akuntansi Universitas Negeri Yogyakarta \\ sriharyani613@gmail.com \\ Dr. Denies Priantinah, M.Si. Ak., CA. \\ Staf Pengajar Jurusan Pendidikan Akuntansi Universitas Negeri Yogyakarta \\ denies_priantinah@uny.ac.id
}

\begin{abstract}
Abstrak : Pengaruh Inflasi, Nilai Tukar Rupiah/Dolar As, Tingkat Suku Bunga Bi, Der, Roa, Cr Dan Npm Terhadap Return Saham. Penelitian ini bertujuan untuk mengetahui pengaruh Inflasi, Nilai Tukar Rupiah Per Dolar AS, Tingkat Suku Bunga BI, DER, ROA, CR, dan NPM terhadap Return Saham baik secara parsial maupun simultan. Sampel penelitian ini sebanyak 34 perusahaan Real Estate and Property yang terdaftar di Bursa Efek Indonesia periode 2012-2016 yang diperoleh dengan metode purposive sampling. Teknik analisis data menggunakan analisis statistik deskriptif, uji asumsi klasik, analisis regresi linear sederhana, dan analisis regresi linear berganda. Hasil penelitian secara parsial menunjukkan bahwa masing-masing variabel Inflasi, Nilai Tukar Rupiah Per Dolar AS, dan Tingkat Suku Bunga BI memiliki pengaruh negatif dan signifikan terhadap Return Saham, sedangkan variabel ROA dan NPM masing-masing memiliki pengaruh positif dan signifikan terhadap Return Saham. Sementara itu, variabel DER memiliki pengaruh positif dan tidak signifikan terhadap Return Saham dan variabel CR memiliki pengaruh negatif dan tidak signifikan terhadap Return Saham. Secara simultan, variabel Inflasi, Nilai Tukar Rupiah Per Dolar AS, Tingkat Suku Bunga BI, DER, ROA, CR, dan NPM memiliki pengaruh yang signifikan terhadap Return Saham.
\end{abstract}

Kata kunci: Inflasi, Nilai Tukar Rupiah Per Dolar AS, Tingkat Suku Bunga BI, DER, ROA, CR, NPM, Real Estate and Property.

Abstract : The Influence Of Inflation, Exchange Rate Of Rupiah/US Dollar, Interest Rate Of BI, DER, ROA, CR, And NPM Toward The Stock Return. This study aims to determine the influence of Inflation, Exchange rate of Rupiah Per US Dollar, Interest Rate of BI, DER, ROA, CR, and NPM toward the Stock Return either partially or simultaneously. The sample of this study was obtained by purposive sampling method and consisted of 34 Real Estate and Property companies listed in Indonesia Stock Exchange in the period of 2012-2016. Data analysis technique used descriptive statistical analysis, classic assumption test, simple linear regression analysis, and multiple linear regression analysis. The result of this study partially show that each variable of Inflation, Exchange Rate of Rupiah Per US Dollar, and Interest Rate of BI have a negative and significant influence toward the Stock Return, while the variables ROA and NPM respectively have a positive and significant influence toward the Stock Return. Meanwhile, the DER variable has a positive and insignificant influence toward the Stock Return and $C R$ variable has a negative and insignificant influence toward the Stock Return. Simultaneously, the variable of Inflation, Exchange rate of Rupiah Per US Dollar, Interest Rate of BI, DER, ROA, CR, and NPM has a significant influence toward the Stock Return.

Keywords: Inflation, Exchange Rate of Rupiah Per US Dollar, Interest Rate of BI, DER, ROA, CR, NPM, Real Estate and Property. 


\section{JURNAL NOMINAL / VOLUME VII NOMOR 2 / TAHUN 2018}

\section{PENDAHULUAN}

Perusahaan dalam meningkatkan labanya dapat menempuh berbagai cara, salah satunya yaitu melalui investasi. Kegiatan investasi merupakan penundaan konsumsi sekarang untuk dimasukkan ke aktiva produktif selama periode waktu tertentu (Hartono, 2014: 5). Adanya penundaan konsumsi sekarang bertujuan untuk memaksimalkan hasil (return) yang diharapkan dalam batas risiko yang dapat diterima untuk masing-masing investor.

Bentuk investasi yang paling populer digunakan adalah saham. Investasi saham memiliki berbagai macam risiko dan ketidakpastian yang sulit untuk diprediksi para investor maupun calon investor. Hal tersebut karena gejolak fluktuasi harga saham yang naik turun dengan cepat. Oleh karena itu, investor menggunakan berbagai macam informasi untuk memprediksi risiko dan ketidakpastian.

Obyek yang digunakan dalam penelitian ini adalah industri Real Estate and Property yang terdaftar di Bursa Efek Indonesia (BEI). Sektor ini dipilih sebagai objek penelitian ini karena sebagai salah satu sektor yang penting di Indonesia. Sektor Real Estate and Property merupakan indikator penting untuk menganalisis kesehatan ekonomi suatu negara. Industri Real Estate and Property ini juga merupakan sektor yang pertama memberi sinyal jatuh atau sedang bangunnya perekonomian suatu negara (Oktavianti \&
Agustia, 2012). Selain alasan tersebut, dipilihnya sektor Real Estate and Property ini sebagai objek penelitian karena sektor ini merupakan salah satu sektor yang memiliki volatilitas yang cukup tinggi oleh kondisi perekonomian secara makro.

Berkembangnya industri Real Estate and Property ini ditandai dengan maraknya pembangunan apartemen, perhotelan, perumahan, perkantoran, pusat perbelanjaan, taman hiburan, dan lain-lain (Hijriah, 2007). Berinvestasi di sektor industri Real Estate and Property ini sangat potensial dan menarik perhatian karena cukup menjanjikan di masa depan. Namun, sektor ini memiliki karakteristik yang sulit untuk diprediksi karena dipengaruhi oleh kondisi perekonomian negara.

Berinvestasi di sektor industri Real Estate and Property ini sangat potensial dan menarik perhatian karena cukup menjanjikan di masa depan. Namun, sektor ini memiliki karakteristik yang sulit untuk diprediksi karena dipengaruhi oleh kondisi perekonomian negara. Pada saat terjadi pertumbuhan ekonomi yang tinggi, industri Real Estate and Property mengalami booming dan cenderung over supplied (Saputra \& Dharmadiaksa, 2016). Sebaliknya, pada saat pertumbuhan ekonomi mengalami penurunan, secara cepat industri ini juga akan mengalami penurunan yang cukup drastis. Hal tersebut tentunya akan berdampak terhadap kinerja perusahaan, khususnya tingkat pendapatan 


\section{JURNAL NOMINAL / VOLUME VII NOMOR 2 / TAHUN 2018}

dan laba yang dihasilkan dalam setiap tahunnya akan mengalami kenaikan dan penurunan yang cukup signifikan.

Menurut Ang (1997: 18), ada dua faktor yang mempengaruhi return saham suatu investasi, yaitu faktor internal dan eksternal perusahaan. Faktor internal dalam penelitian ini menggunakan rasio keuangan perusahaan yang terdiri dari DER, ROA, CR, dan NPM. Adapun faktor eksternal untuk mewakili kondisi makroekonomi yaitu Inflasi, Nilai Tukar Rupiah Per Dolar AS, dan Tingkat Suku Bunga BI.

Naiknya inflasi menunjukkan bahwa suatu risiko untuk melakukan investasi adalah cukup tinggi, sebab tingkat inflasi yang tinggi akan mengurangi tingkat pengembalian (rate of return) dari para investor. Saat tingkat inflasi tinggi, maka terjadi akibat adanya total permintaan yang berlebihan dimana biasanya dipicu oleh membanjirnya likuiditas di pasar sehingga terjadi permintaan yang tinggi dan memicu perubahan pada tingkat harga. Bertambahnya permintaan barang dan jasa tersebut mengakibatkan bertambahnya permintaan terhadap faktor-faktor produksi, sehingga biaya produksi menjadi naik. Kenaikan biaya produksi dapat mengurangi tingkat pendapatan perusahaan, sehingga akan memberikan dampak buruk terhadap kinerja perusahaan yang akan tercermin pada menurunnya return saham (Djayani, 1999).
Naik turunnya nilai tukar suatu mata uang juga dapat memengaruhi nilai pasar dan kegiatan pasar lokal. Bagi investor, melemahnya nilai tukar rupiah mengindikasikan bahwa faktor fundamental Indonesia sedang melemah. Hal tersebut menyebabkan para investor beranggapan bahwa berinvestasi dalam bentuk saham memiliki risiko yang cukup tinggi. Investor yang termasuk risk-averse tentunya ia akan memilih untuk menghindari risiko, sehingga investor akan cenderung melakukan aksi jual saham hingga perekonomian dirasa sudah mulai membaik. Aksi jual yang dilakukan oleh investor akan mendorong penurunan harga saham di bursa efek. Harga saham yang menurun akan mengakibatkan return saham mengalami penurunan pula.

Selain inflasi dan nilai tukar, perubahan tingkat suku bunga BI akan memberikan pengaruh bagi pasar keuangan dan pasar modal. Apabila tingkat suku bunga BI mengalami kenaikan, maka secara langsung akan meningkatkan beban bunga perusahaan. Perusahaan yang memiliki tingkat leverage tinggi akan mendapatkan dampak yang berat terhadap kenaikan tingkat bunga. Kenaikan tingkat suku bunga tersebut juga dapat mengurangi profitabilitas perusahaan, sehingga dapat memberikan pengaruh terhadap harga saham perusahaan yang bersangkutan. Jika harga saham perusahaan yang bersangkutan 


\section{JURNAL NOMINAL / VOLUME VII NOMOR 2 / TAHUN 2018}

menurun, maka return saham yang akan diterima oleh investor juga menurun.

Faktor lain yang mempengaruhi return suatu investasi yaitu faktor internal perusahaan. Faktor internal yang digunakan dalam penelitian ini adalah DER, ROA, CR, dan NPM. DER yang semakin besar menandakan bahwa struktur permodalan usaha lebih banyak memanfaatkan hutanghutang relatif terhadap ekuitas, sehingga mencerminkan risiko perusahaan akan semakin tinggi dan para investor akan cenderung menghindari saham-saham yang memiliki nilai DER yang tinggi. Prihantini (2009: 8-9) menyatakan bahwa penggunaan hutang oleh suatu perusahaan akan membuat risiko yang ditanggung pemegang saham semakin meningkat. Ketika terdapat penambahan jumlah hutang secara absolut, maka akan menurunkan tingkat solvabilitas perusahaan, yang selanjutnya akan berdampak dengan menurunnya return saham perusahaan.

Rasio profitabilitas yang digunakan untuk memprediksi Return Saham adalah ROA dan NPM. ROA digunakan untuk mengukur efektivitas perusahaan dalam memanfaatkan aktiva yang dimiliknya. Jika ROA semakin meningkat, maka kinerja perusahaan menjadi semakin membaik, karena tingkat pengembalian yang diharapkan semakin tinggi (Hardiningsih, Suryanto, \& Chariri 2002). Bahkan, Ang (1997: 35) mengatakan bahwa ROA merupakan rasio yang terpenting diantara rasio profitabilitas yang ada untuk memprediksi return saham. Jika nilai ROA yang dihasilkan dalam industri Real Estate and Property semakin kecil, maka mengindikasikan berkurangnya kemampuan manajemen dalam mengelola aktiva untuk menekan biaya dan meningkatkan pendapatan. Tentunya hal tersebut dapat mempengaruhi pergerakan harga saham yang berdampak pada menurunnya Return Saham.

$$
\text { Rasio profitabilitas yang }
$$
diasosiasikan dengan NPM mencerminkan seberapa besar kemampuan perusahaan dalam menghasilkan laba pada tingkat penjualan tertentu (Hanafi, 2014: 42). Apabila sebuah perusahaan dapat menghasilkan NPM yang tinggi, maka perusahaan tersebut dapat dikatakan memiliki kinerja yang baik dan produktif. Jadi, dengan adanya peningkatan dari NPM, maka akan mempengaruhi tingginya tingkat pengembalian return saham pada pihak investor.

Likuiditas perusahaan merupakan kemampuan perusahaan untuk memenuhi kewajiban finansial pada saat ditagih. Rasio likuiditas yang digunakan dalam penelitian ini adalah CR. CR merupakan rasio untuk mengukur kemampuan perusahaan dalam membayar kewajiban jangka pendek atau hutang yang segera jatuh tempo pada saat ditagih secara keseluruhan (Kasmir, 2016: 134). Semakin besar nilai $C R$ suatu perusahaan, maka menunjukkan bahwa 


\section{JURNAL NOMINAL / VOLUME VII NOMOR 2 / TAHUN 2018}

semakin besar pula kemampuan perusahaan dalam memenuhi

kebutuhan operasionalnya terutama modal kerja yang sangat penting untuk menjaga kinerja perusahaan yang pada akhirnya mempengaruhi performance harga saham. Hal tersebut akan memberikan keyakinan pada investor untuk memiliki saham perusahaan tersebut sehingga dapat meningkatkan return saham.

Berdasarkan pemaparan teori di atas, pada kenyataanya tidak semua teori yang telah dipaparkan di atas sejalan dengan bukti empiris yang ada. Hal tersebut sama dengan kondisi yang terjadi dalam industri Real Estate and Property yang listed di BEI periode 2012-2016. Adapun besarnya rata-rata Return Saham industri Real Estate and Property yang listed di BEI periode 2012-2016 adalah dalam Tabel 2 berikut.

Tabel 1. Rata-rata Return Saham, Inflasi, Nilai Tukar Rupiah per Dolar AS, Tingkat Suku Bunga BI, DER, ROA, CR, dan NPM periode 2012-2016.

\begin{tabular}{llllll}
\hline Variabel & $\mathbf{2 0 1 2}$ & $\mathbf{2 0 1 3}$ & $\mathbf{2 0 1 4}$ & $\mathbf{2 0 1 5}$ & $\mathbf{2 0 1 6}$ \\
\hline $\begin{array}{l}\text { Return } \\
\text { Saham }\end{array}$ & 0,38 & 0,39 & 0,34 & $-0,08$ & 0,15 \\
\hline $\begin{array}{l}\text { Nilai } \\
\text { Tukar } \\
\text { Rp/Dolar } \\
\text { AS }\end{array}$ & $9.384,24$ & $10.459,09$ & $11.868,67$ & $13.389,41$ & $13.308,33$ \\
\hline $\begin{array}{l}\text { Tingkat } \\
\text { Suku } \\
\text { Bunga BI }\end{array}$ & $5,77 \%$ & $6,48 \%$ & $7,53 \%$ & $7,52 \%$ & $6,00 \%$ \\
\hline DER & 0.67 & 0,71 & 0,75 & 0,70 & 0,73 \\
\hline ROA & $-0,12$ & 0,07 & 0,07 & 0,05 & 0,06 \\
\hline CR & 1,81 & 1,87 & 1,89 & 2,00 & 2,60 \\
\hline NPM & 0,81 & 0,95 & $-0,01$ & 0,23 & 0,21
\end{tabular}

Sumber: data sekunder diolah, 2018.
Berdasarkan Tabel 1 tersebut, terlihat bahwa ada beberapa nilai Inflasi, Nilai Tukar Rupiah per Dolar AS, DER, ROA, CR, dan NPM menunjukkan kondisi yang tidak konsisten dengan Return Saham pada industri Real Estate and Property yang listed di Bursa Efek Indonesia periode 2012 hingga 2016. Misalnya Inflasi dari tahun 2012 ke 2013 mengalami kenaikan, tetapi justru Return Saham naik, padahal risiko mengalami kenaikan. Begitu juga dengan Nilai Tukar Rupiah per Dolar AS, DER, ROA, CR, dan NPM pada tahun tertentu.

Melihat fenomena Return Saham industri Real Estate and Property selama periode 2012 hingga 2016 inilah yang menjadi salah satu dasar bagi peneliti untuk mengkaji lebih mendalam mengenai faktorfaktor apa sajakah yang diperkirakan dapat mempengaruhi Return Saham. Selain itu, dari beberapa penelitian terdahulu juga memberikan hasil yang tidak konsisten. Oleh karena itu, melakukan penelitian dengan judul "Pengaruh Inflasi, Nilai Tukar Rupiah/Dolar AS, Suku Bunga BI, DER, ROA, CR, dan NPM terhadap Return Saham".

\section{METODE PENELITIAN}

\section{Jenis Penelitian}

Penelitian ini merupakan jenis penelitian asosiatif. Penelitian asosiatif adalah penelitian yang menjelaskan hubungan antara dua variabel atau lebih (Sugiyono, 2016: 61). Selain itu, penelitian 


\section{JURNAL NOMINAL / VOLUME VII NOMOR 2 / TAHUN 2018}

ini menggunakan pendekatan ex postfacto, yaitu penelitian yang dilakukan untuk meneliti peristiwa yang telah terjadi dan kemudian merunut ke belakang untuk mengetahui faktor-faktor yang dapat menimbulkan kejadian tersebut (Sugiyono, 2014: 7). Jika dilihat dari data yang digunakan, penelitian ini merupakan jenis penelitian kuantitatif karena di dalamnya mengacu pada perhitungan data penelitian yang berupa angka-angka (Sugiyono, 2013: 147).

\section{Waktu dan Tempat Penelitian}

Pengambilan data nilai Inflasi, Nilai Tukar Rupiah Per Dolar AS, dan Tingkat Suku Bunga BI diperoleh melalui website resmi Bank Indonesia yaitu www.bi.go.id. DER, ROA, CR, dan NPM diperoleh melalui laporan keuangan perusahaan yang dipublikasikan di situs idx.co.id dari tahun 2012 hingga 2016. Data Return Saham diperoleh melalui situs resmi yahoo yaitu www.finance.yahoo.com. Pengambilan data yang digunakan dalam penelitian ini dilakukan pada tanggal 28 Januari 2018 hingga 17 Februari 2018.

\section{Populasi dan Sampel Penelitian}

Populasi dalam penelitian ini adalah industri Real Estate and Property periode 2012-2016. Metode penentuan sampel menggunakan purposive sampling dan ada sebanyak 34 perusahaan yang memenuhi kriteria.

\section{Definisi Operasional Variabel}

a. Return Saham

Return Saham adalah tingkat keuntungan yang dinikmati oleh pemodal atas investasi yang dilakukannya. Menurut Hartono (2014: 264), besarnya Return Saham dirumuskan sebagai berikut.

$$
R_{t}=\frac{P_{t}-P_{t-1}}{P_{t-1}}
$$

Keterangan:

$\mathrm{R}_{\mathrm{t}}=$ Return Saham

$\mathrm{P}_{\mathrm{t}}=$ Harga saham saat ini

$\mathrm{P}_{\mathrm{t}-1}=$ Harga saham periode sebelumnya

b. Inflasi

Inflasi merupakan suatu keadaan dimana terjadi kelebihan suatu permintaan atas barang-barang di dalam suatu perekonomian secara menyeluruh. Variabel Inflasi dalam penelitian ini diukur dengan menggunakan laju inflasi per Desember selama periode penelitian 2012 hingga 2016. Pengukuran laju inflasi dilakukan dalam satuan persen.

c. Nilai Tukar Rupiah Per Dolar AS

Nilai Tukar Rupiah Per Dolar AS menunjukkan nilai dari mata uang dolar AS yang ditranslasikan atau dijabarkan ke dalam mata uang rupiah. Variabel Nilai Tukar Rupiah Per Dolar AS dalam penelitian ini diukur dengan menggunakan nilai rata-rata kurs tengah rupiah terhadap dolar AS per 31 Desember selama periode penelitian 2012 hingga 2016. 


\section{JURNAL NOMINAL / VOLUME VII NOMOR 2 / TAHUN 2018}

d. Tingkat Suku Bunga BI

Tingkat Suku Bunga BI adalah suku bunga kebijakan yang mencerminkan sikap atau stance kebijakan yang ditetapkan oleh Bank Indonesia dan diumumkan kepada publik. Variabel Tingkat Suku Bunga BI dalam penelitian ini diukur dengan menggunakan Tingkat Suku Bunga BI bulanan yang ditetapkan oleh Bank Indonesia per Desember selama periode penelitian 2012 hingga 2016.

e. Debt to Equity Ratio (DER)

DER merupakan perbandingan antara total hutang terhadap total ekuitas yang dimiliki perusahaan. Total hutang di sini merupakan total hutang jangka pendek dan total hutang jangka panjang. Rumus DER menurut Sawir (2009: 13):

$$
D E R=\frac{\text { Total Liabilitas }}{\text { Total Ekuitas }}
$$

\section{f. Return on Asset (ROA)}

ROA merupakan rasio profitabilitas yang digunakan untuk mengukur efektifitas perusahaan dalam menghasilkan keuntungan bersih dengan memanfaatkan aktiva yang dimilikinya. Berikut adalah rumus untuk menghitung nilai ROA menurut Syamsuddin (2009: 63).

$$
R O A=\frac{\text { Laba Setelah Pajak }}{\text { Total Aset }}
$$

\section{g. Current Ratio (CR)}

CR merupakan rasio yang digunakan untuk mengukur sejauh mana kemampuan perusahaan dalam memenuhi kewajiban jangka pendeknya. Berikut adalah rumus untuk menghitung nilai $\mathrm{CR}$ (Fahmi, 2011: 137).

$$
C R=\frac{\text { Current Assets }}{\text { Current Liabilities }}
$$

h. Net Profit Margin (NPM)

NPM merupakan perbandingan antara laba bersih setelah dipotong pajak dengan penjualan. Menurut Sartono (2010: 123), NPM dihitung dengan menggunakan rumus berikut.

$$
N P M=\frac{\text { Laba Setelah Pajak }}{\text { Penjualan }}
$$

Data, Intrumen, dan Teknik Pengumpulan

a. Data

Data yang digunakan dalam penelitian ini adalah data kuantitatif. Data kuantitatif merupakan data yang dinyatakan dalam satuan angka. Metode pengumpulan data yang digunakan dalam penelitian ini adalah metode dokumentasi. Metode dokumentasi merupakan metode pengambilan data dengan cara mengumpulkan catatan-catatan yang menjadi bahan penelitian. Dokumentasi digunakan untuk memperoleh data Return Saham, Inflasi, Nilai Tukar Rupiah Per Dolar AS, Tingkat Suku Bunga BI, DER, ROA, CR, dan NPM. 
JURNAL NOMINAL / VOLUME VII NOMOR 2 / TAHUN 2018

\section{b. Teknik Analisis Data}

Teknik analisis data menggunakan analisis statistik deskriptif, uji asumsi klasik, analisis regresi linear sederhana, dan analisis regresi linear berganda.

\section{HASIL PENELITIAN DAN}

\section{PEMBAHASAN}

\section{Analisis Statistik Deskriptif}

a. Return Saham

Distribusi data Return Saham paling banyak berada di range -0,05 sampai 0,17 dengan persentase $28,15 \%$ dan memiliki frekuensi 38. Distribusi data Return Saham paling sedikit berada diantara range 1,10 hingga 1,32 dengan persentase $1,48 \%$ dan frekuensi 2. Hasil ini dapat dilihat pada histogram berikut.

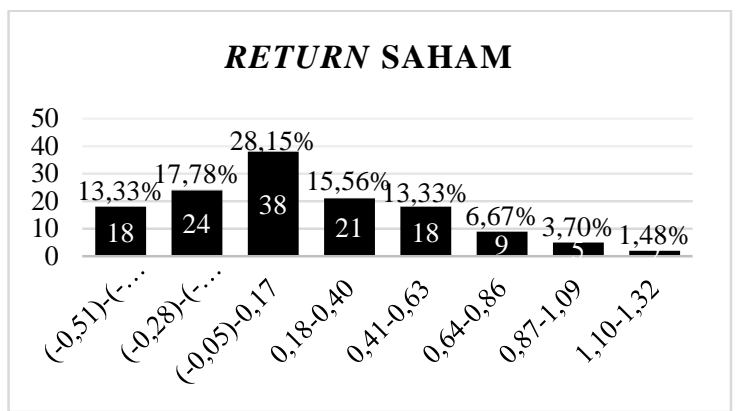

Sumber: data sekunder diolah, 2018.

Gambar 2. Histogram Return Saham

b. Inflasi

Distribusi data Inflasi paling banyak berada di range 7,78 sampai 8,45 dengan persentase $42,22 \%$ dan memiliki frekuensi 57. Distribusi data Inflasi paling sedikit berada diantara range 4,38-5,05; 5,06-5,73; 5,74-6,41; 6,42-7,09; dan 7,10-7,77 dengan persentase $0 \%$ dan frekuensi 0 . Hasil ini dapat dilihat pada histogram berikut.

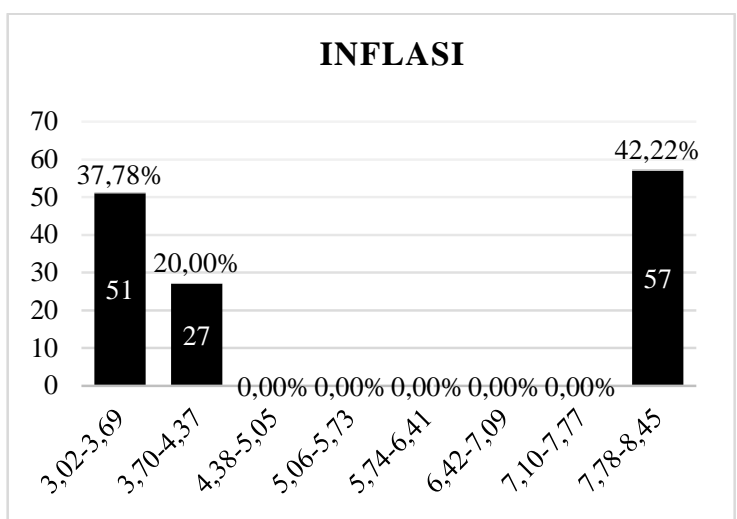

Sumber: data sekunder diolah, 2018.

Gambar 3. Histogram Inflasi

c. Nilai Tukar Rupiah Per Dolar AS

Distribusi data Nilai Tukar Rupiah per Dolar AS paling banyak berada di range 12890,62 sampai 13392,07 dengan persentase $37,78 \%$ dan memiliki frekuensi 51. Distribusi data Nilai Tukar Rupiah per Dolar AS paling sedikit berada diantara range 9881,85-10383,31; 10884,7811386,23; 11887,70-12389,15; dan 12389,16-12890,61 dengan persentase 0\% dan frekuensi 0. Hasil ini dapat dilihat pada histogram berikut.

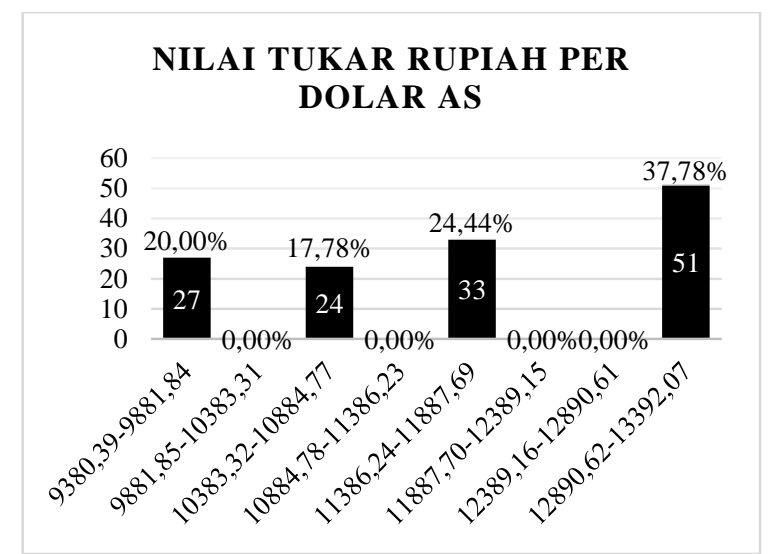

Sumber: data sekunder diolah, 2018.

Gambar 4. Histogram Nilai Tukar Rupiah Per Dolar AS 
JURNAL NOMINAL / VOLUME VII NOMOR 2 / TAHUN 2018

d. Tingkat Suku Bunga BI

Distribusi data Tingkat Suku Bunga BI paling banyak berada di range $7,48 \%$ sampai $7,86 \%$ dengan persentase $61,48 \%$ dan memiliki frekuensi 83. Distribusi data Tingkat Suku Bunga BI paling sedikit berada diantara range 5,92-6,30; 5,14-5,52; 6,31-6,69; 6,70-7,08; dan 7,09-7,47 dengan persentase $0 \%$ dan frekuensi 0 . Hasil ini dapat dilihat pada histogram berikut.

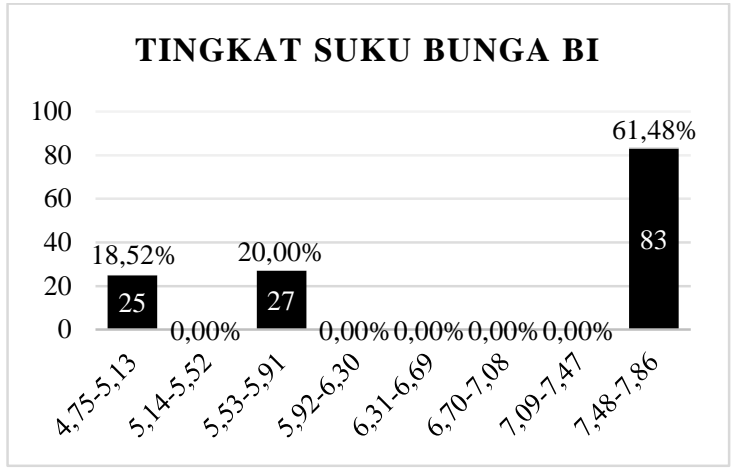

Sumber: data sekunder diolah, 2018.

Gambar 5. Histogram Tingkat Suku Bunga BI

\section{e. Debt to Equity Ratio (DER)}

Distribusi data DER paling banyak berada di range 0,53 sampai 0,77 dengan persentase $28,89 \%$ dan memiliki frekuensi 39. Distribusi data DER paling sedikit berada diantara range 1,78 hingga 2,02 dengan persentase 2,22\% dan frekuensi 3 . Hasil ini dapat dilihat pada histogram berikut.
DEBT TO EQUITY RATIO (DER)

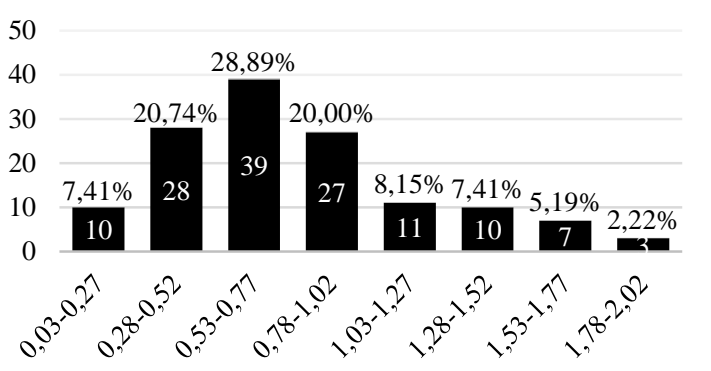

Sumber: data sekunder diolah, 2018.

Gambar 6. Histogram DER

\section{f. Return on Asset (ROA)}

Distribusi data ROA paling banyak berada di range 0,009 sampai 0,047 dengan persentase $33,33 \%$ dan memiliki frekuensi 45. Distribusi data ROA paling sedikit berada diantara range 0,204 hingga 0,242 dengan persentase $0,74 \%$ dan frekuensi 1 . Hasil ini dapat dilihat pada histogram berikut.

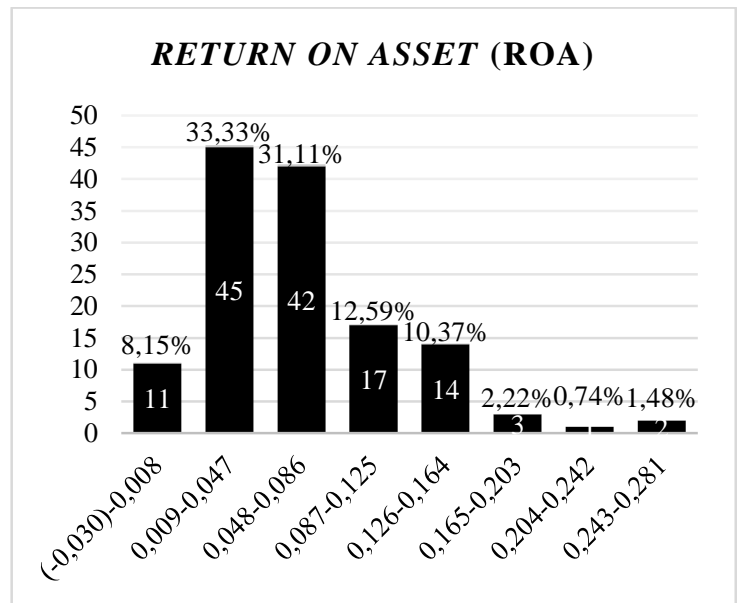

Sumber: data sekunder diolah, 2018.

Gambar 7. Histogram RO

\section{g. Current Ratio (CR)}

Distribusi data CR paling banyak berada di range 0,92 sampai 1,59 dengan persentase $31,11 \%$ dan memiliki frekuensi 42. Distribusi data CR paling sedikit berada 
JURNAL NOMINAL / VOLUME VII NOMOR 2 / TAHUN 2018

diantara range 4,32-4,99 dan 5,00-5,67 dengan persentase masing-masing 2,96\% dan frekuensi 4. Hasil ini dapat dilihat pada histogram berikut.

\section{CURRENT RATIO (CR)}

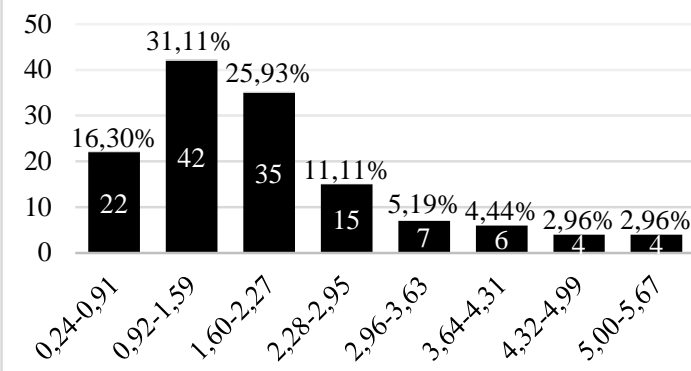

Sumber: data sekunder diolah, 2018.

Gambar 8. Histogram CR

\section{h. Net Progit Margin (NPM)}

Distribusi data NPM paling banyak berada di range 0,15 sampai 0,26 dengan persentase $33,33 \%$ dan memiliki frekuensi 45. Distribusi data NPM paling sedikit berada diantara range 0,75 hingga 0,86 dengan persentase $0,74 \%$ dan frekuensi 1 . Hasil ini dapat dilihat pada histogram berikut.

NET PROFIT MARGIN (NPM)

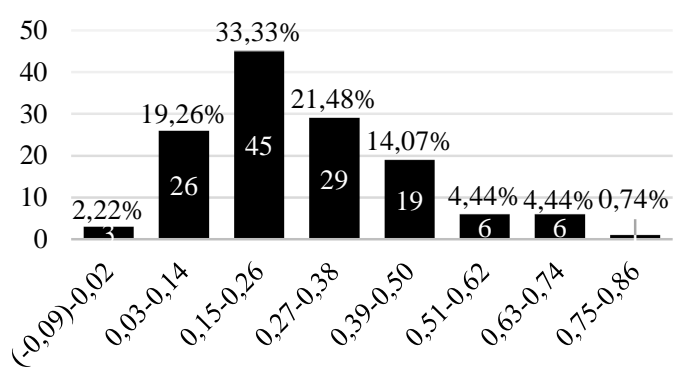

Sumber: data sekunder diolah, 2018.

Gambar 9. Histogram NPM

\section{Uji Asumsi Klasik}

a. Uji Normalitas

Berdasarkan uji normalitas, dapat dilihat bahwa nilai signifikansi
Kolmogorov-Smirnov adalah 0,200. Nilai tersebut lebih besar dari 0,05. Dengan demikian, dapat disimpulkan bahwa data dalam penelitian ini berdistribusi normal.

Tabel 1. Hasil Uji Normalitas

\begin{tabular}{ccc}
\hline Variabel & $\begin{array}{c}\text { Asymp. } \\
\text { Sig. (2- }\end{array}$ & Kesimpulan \\
& tailed) & \\
\hline Unstandarized & 0,200 & Normal \\
Residual & & \\
\hline
\end{tabular}

b. Uji Multikolinearitas

Berdasarkan uji multikolinearitas, nilai Tolerance dari semua variabel independen adalah lebih besar dari 0,10 dan nilai VIF kurang dari 10. Dengan demikian, dapat disimpulkan bahwa model regresi yang digunakan dalam penelitian ini tidak memiliki masalah multikolinearitas.

Tabel 2. Hasil Uji Multikolinearitas

\begin{tabular}{lcc}
\hline \multicolumn{1}{c}{ Variabel } & Tolerance & VIF \\
\hline Inflasi $\left(\mathbf{X}_{\mathbf{1}}\right)$ & 0,906 & 1,104 \\
\hline Nilai Tukar $\left(\mathbf{X}_{\mathbf{2}}\right)$ & 0,936 & 1,069 \\
\hline Suku Bunga $\left(\mathbf{X}_{\mathbf{3}}\right)$ & 0,893 & 1,120 \\
\hline DER $\left(\mathbf{X}_{\mathbf{4}}\right)$ & 0,933 & 1,072 \\
\hline ROA $\left(\mathbf{X}_{\mathbf{5}}\right)$ & 0,338 & 2,959 \\
\hline CR $\left(\mathbf{X}_{\mathbf{6}}\right)$ & 0,949 & 1,053 \\
\hline NPM $\left(\mathbf{X}_{\mathbf{7}}\right)$ & 0,326 & 3,063
\end{tabular}

c. Uji Heteroskedastisitas

Berdasarkan uji heteroskedatisitas, dapat dilihat bahwa parameter koefisien untuk semua variabel independen memiliki nilai signifikansi di atas 0,05. Hal ini menunjukkan bahwa model regresi tidak memiliki masalah heteroskedastisitas. 
JURNAL NOMINAL / VOLUME VII NOMOR 2 / TAHUN 2018

Tabel 3. Hasil Uji Heteroskedatisitas

\begin{tabular}{llc}
\hline \multicolumn{2}{c}{ Model } & Sig. \\
\hline 1 & (Constant $)$ &, 441 \\
\cline { 2 - 2 } & INFLASI &, 941 \\
\hline NILAI_TUKAR &, 058 \\
\hline SUKU_BUNGA &, 756 \\
\hline DER &, 159 \\
\hline ROA &, 161 \\
\hline CR &, 683 \\
\hline NPM &, 161 \\
\hline
\end{tabular}

c. Uji Autokorelasi

Berdasarkan hasil uji autokorerlasi, dilihat bahwa parameter koefisien residual lag 2 (Res_2) memiliki nilai signifikansi 0,373 dan di atas 0,05. Hal ini menunjukkan bahwa model regresi tidak terdapat masalah autokorelasi.

Tabel 4. Hasil Uji Autokorelasi

\begin{tabular}{llc}
\hline \multicolumn{2}{c}{ Model } & Sig. \\
\hline 1 & (Constant $)$ &, 916 \\
\cline { 2 - 2 } & INFLASI &, 925 \\
\cline { 2 - 2 } NILAI_TUKAR &, 860 \\
\hline SUKU_BUNGA &, 936 \\
\hline DER &, 865 \\
\hline ROA &, 885 \\
\hline CR &, 974 \\
\hline NPM &, 883 \\
\hline Res_2 &, 373 \\
\hline
\end{tabular}

\section{d. Uji Linearitas}

Berdasarkan uji linearitas, menunjukkan bahwa nilai $\mathrm{C}^{2}{ }_{\text {hitung lebih kecil }}$ dari nilai $\mathrm{C}_{\text {tabel, sehingga dapat }}^{2}$ disimpulkan bahwa model regresi dalam penelitian ini adalah linear.
Tabel 5. Hasil Uji Linearitas

\begin{tabular}{cccc}
\hline Model & $\mathbf{R}^{\mathbf{2}}$ & $\mathbf{C}^{2}{ }_{\text {hitung }}$ & $\mathbf{C}^{2}$ tabel \\
\hline $\mathbf{1}$ & 0,080 & 0,81 & 163,12 \\
\hline
\end{tabular}

\section{Pengujian Hipotesis}

a. Pengujian Hipotesis Pertama

Ringkasan uji hipotesis pertama dapat dilihat pada tabel berikut.

Tabel 6. Hasil Pengujian Hipotesis Pertama

\begin{tabular}{ll}
\hline \multicolumn{1}{c}{ Informasi } & Nilai \\
\hline Konstanta & 0,343 \\
\hline Koefisien & $-0,034$ \\
\hline $\mathbf{R}^{\mathbf{2}}$ & 0,045 \\
\hline $\mathbf{t}_{\text {hitung }}$ & $-2,513$ \\
\hline $\mathbf{t}_{\text {tabel }}$ & 1,656 \\
\hline Sig. & 0,013
\end{tabular}

Berdasarkan Tabel 6, persamaan regresi linear sederhana dalam uji hipotesis pertama adalah sebagai berikut.

$$
\begin{gathered}
R E T U R N \_S A H A M=0,343-0,034 \\
\text { INFLASI }
\end{gathered}
$$

Nilai koefisien regresi adalah 0,343 dan nilai thitung sebesar 2,513 yang mana lebih besar dari tabel 1,656. Tingkat signifikansi sebesar 0,013 yang mana lebih kecil dari 0,05. Hal ini menunjukkan bahwa Inflasi berpengaruh negatif dan signifikan terhadap Return Saham.

Inflasi yang tinggi akan mengakibatkan penurunan harga saham, karena menyebabkan kenaikan harga barang secara umum akibat permintaan untuk memenuhi kebutuhan masyarakat yang semakin tinggi. Kenaikan harga-harga tersebut juga akan berdampak pada 


\section{JURNAL NOMINAL / VOLUME VII NOMOR 2 / TAHUN 2018}

kenaikan biaya produksi dalam industri Real Estate and Property, sehingga manajemen harus menaikkan harga jual produknya. Kenaikan biaya produksi menyebabkan laba perusahaan menjadi menururn. Bagi investor, hal tersebut adalah berita yang buruk. Investor akan melepas saham yang dimiliki ketika terjadi inflasi yang tinggi, sehingga pada akhirnya Return Saham juga mengalami penurunan.

b. Pengujian Hipotesis Kedua

Ringkasan uji hipotesis kedua dapat dilihat pada tabel berikut.

Tabel 7. Hasil Pengujian Hipotesis Kedua

\begin{tabular}{lc}
\hline \multicolumn{1}{c}{ Informasi } & Nilai \\
\hline Konstanta & 1,215 \\
\hline Koefisien & $-0,00009$ \\
\hline $\mathbf{R}^{\mathbf{2}}$ & 0,137 \\
\hline $\mathbf{t}_{\text {hitung }}$ & $-4,588$ \\
\hline $\mathbf{t}_{\text {tabel }}$ & 1,656 \\
\hline Sig. & 0,000 \\
\hline
\end{tabular}

Berdasarkan Tabel 7, persamaan regresi linear sederhana dalam uji hipotesis kedua adalah sebagai berikut.

$$
\begin{gathered}
R E T U R N \_S A H A M=1,215-0,00009 \\
\text { NILAI_TUKAR }
\end{gathered}
$$

Nilai koefisien regresi adalah 1,215 dan nilai thitung sebesar 4,588 yang mana lebih besar dari tabel 1,656. Tingkat signifikansi sebesar 0,000 yang mana lebih kecil dari 0,05. Hal ini menunjukkan bahwa Nilai Tukar Rupiah Per Dolar AS berpengaruh negatif dan signifikan terhadap Return Saham.

Ketika nilai tukar rupiah terhadap dolar AS melemah, maka akan memberikan pengaruh terhadap pasar ekuitas, karena pasar ekuitas menjadi tidak punya daya tarik dari investor. Sebab investor akan lebih cenderung menyimpan uang dalam bentuk dolar AS. Selain itu, dengan melemahnya nilai tukar rupiah terhadap dolar AS akan mempengaruhi kinerja perusahaan Real Estate and Property, sebab banyak perusahaan yang memiliki pinjaman luar negeri dalam bentuk dolar AS untuk membiayai proyek jangka panjang maupun untuk pembelian bangunan.

c. Pengujian Hipotesis Ketiga

Ringkasan uji hipotesis ketiga dapat dilihat pada tabel berikut.

Tabel 8. Hasil Pengujian Hipotesis Ketiga

\begin{tabular}{ll}
\hline \multicolumn{1}{c}{ Informasi } & Nilai \\
\hline Konstanta & 0,672 \\
\hline Koefisien & $-0,077$ \\
\hline $\mathbf{R}^{\mathbf{2}}$ & 0,057 \\
\hline $\mathbf{t}_{\text {hitung }}$ & $-2,846$ \\
\hline $\mathbf{t}_{\text {tabel }}$ & 1,656 \\
\hline Sig. & 0,005
\end{tabular}

Berdasarkan Tabel 8, persamaan regresi linear sederhana dalam uji hipotesis ketiga adalah sebagai berikut.

$$
\begin{gathered}
\text { RETURN_SAHAM }=0,672-0,077 \\
\text { SUKU_BUNGA }
\end{gathered}
$$

Nilai koefisien regresi adalah 0,672 dan nilai thitung sebesar 2,846 yang mana lebih besar dari tabel 1,656. Tingkat signifikansi sebesar 0,005 yang mana lebih kecil dari 0,05. Hal ini menunjukkan bahwa Tingkat Suku Bunga BI berpengaruh negatif dan signifikan terhadap Return Saham. 


\section{JURNAL NOMINAL / VOLUME VII NOMOR 2 / TAHUN 2018}

Kenaikan Suku Bunga BI akan meningkatkan beban bunga emiten, sehingga laba perusahaan akan terpangkas. Selain itu, ketika Tingkat Suku Bunga BI tinggi, biaya produksi akan meningkat dan harga produk akan menjadi lebih mahal, sehingga konsumen mungkin akan menunda pembeliannya dan menyimpan dananya di bank. Akibatnya penjualan perusahaan akan mengalami penurunan. Penurunan penjualan perusahaan dan laba akan menekan harga saham sehingga akan menurunkan Return Saham perusahaan tersebut. Kesimpulannya jika Tingkat Suku Bunga BI meningkat, sebaiknya investor menjual sahamnya dan dapat beralih ke pasar saham obligasi, begitu pula sebaliknya.

d. Pengujian Hipotesis Keempat

Ringkasan uji hipotesis keempat dapat dilihat pada tabel berikut.

Tabel 9.Hasil Pengujian Hipotesis Keempat

\begin{tabular}{ll}
\hline \multicolumn{1}{c}{ Informasi } & Nilai \\
\hline Konstanta & 0,126 \\
\hline Koefisien & 0,036 \\
\hline $\mathbf{R}^{2}$ & 0,032 \\
\hline $\mathbf{t}_{\text {hitung }}$ & 0,453 \\
\hline $\mathbf{t}_{\text {tabel }}$ & 1,656 \\
\hline Sig. & 0,652
\end{tabular}

Berdasarkan Tabel 9, persamaan regresi linear sederhana dalam uji hipotesis keempat adalah sebagai berikut.

$$
\text { RETURN_SAHAM }=0,126+0,036 \text { DER }
$$

Nilai koefisien regresi adalah 0,126 dan nilai thitung sebesar 0,453 yang mana lebih kecil dari $t_{\text {tabel }}$ 1,656. Tingkat signifikansi sebesar 0,652 yang mana lebih besar dari 0,05. Hal ini menunjukkan bahwa DER berpengaruh positif dan tidak signifikan terhadap Return Saham.

Sesuai dengan teori saham bahwa high risk - high return, dimana risiko dari suatu perusahaan ditandai dengan tingkat DER yang dimilikinya. Oleh sebagian investor, DER dipandang sebagai besarnya tanggungjawab perusahaan terhadap pihak ketiga (kreditur) yang memberikan pinjaman kepada perusahaan. Namun demikian, nampaknya beberapa investor justru memandang bahwa perusahaan yang tumbuh pasti akan memerlukan hutang sebagai dana tambahan untuk memenuhi pendanaan pada perusahan yang tumbuh. Perusahaan tersebut memerlukan banyak dana operasional yang tidak mungkin dapat dipenuhi hanya dari modal sendiri yang dimiliki perusahaan. Kondisi ini menyebabkan kemungkinan berkembangnya perusahaan di masa yang akan datang yang berujung pada meningkatnya Return Saham.

e. Pengujian Hipotesis Kelima

Ringkasan uji hipotesis kelima dapat dilihat pada tabel berikut. 
JURNAL NOMINAL / VOLUME VII NOMOR 2 / TAHUN 2018

Tabel 10. Hasil Pengujian Hipotesis Kelima

\begin{tabular}{ll}
\hline \multicolumn{1}{c}{ Informasi } & Nilai \\
\hline Konstanta & $-0,045$ \\
\hline Koefisien & 2,900 \\
\hline $\mathbf{R}^{2}$ & 0,156 \\
\hline $\mathbf{t}_{\text {hitung }}$ & 4,950 \\
\hline $\mathbf{t}_{\text {tabel }}$ & 1,656 \\
\hline Sig. & 0,000 \\
\hline
\end{tabular}

Berdasarkan Tabel 10, persamaan regresi linear sederhana dalam uji hipotesis kelima adalah sebagai berikut.

RETURN_SAHAM $=-0,045+2,900$ ROA

Nilai koefisien regresi adalah $-0,045$ dan nilai thitung sebesar 4,950 yang mana lebih besar dari tabel 1,656. Tingkat signifikansi sebesar 0,000 yang mana lebih kecil dari 0,05. Hal ini menunjukkan bahwa ROA berpengaruh positif dan signifikan terhadap Return Saham.

Tingkat profitabilitas perusahaan yang baik tentu akan menarik minat investor untuk memiliki saham perusahaan tersebut, karena ROA yang tinggi akan meningkatkan tingkat pengembalian (return) yang dapat dinikmati oleh investor. Dengan demikian, dapat dikatakan bahwa semakin tinggi ROA menunjukkan semakin efektif perusahaan memanfaatkan asetnya untuk menghasilkan laba bersih setelah pajak. Jika minat investor untuk membeli saham suatu perusahaan meningkat, maka harga saham perusahaan tersebut juga cenderung meningkat diikuti oleh tingkat pengembalian (return) saham yang tinggi. f. Pengujian Hipotesis Keenam

Ringkasan uji hipotesis keenam dapat dilihat pada tabel berikut.

Tabel 11. Hasil Pengujian Hipotesis Keenam

\begin{tabular}{ll}
\hline \multicolumn{1}{c}{ Informasi } & Nilai \\
\hline Konstanta & 0,181 \\
\hline Koefisien & $-0,014$ \\
\hline $\mathbf{R}^{2}$ & 0,002 \\
\hline $\mathbf{t}_{\text {hitung }}$ & $-0,484$ \\
\hline $\mathbf{t}_{\text {tabel }}$ & 1,656 \\
\hline Sig. & 0,629 \\
\hline
\end{tabular}

Berdasarkan Tabel 11, persamaan regresi linear sederhana dalam uji hipotesis keenam adalah sebagai berikut.

$$
\text { RETURN_SAHAM }=0,181-0,014 \text { CR }
$$

Nilai koefisien regresi adalah 0,181 dan nilai $t_{\text {hitung }}$ sebesar 0,484 yang mana lebih kecil dari $t_{\text {tabel }}$ 1,656. Tingkat signifikansi sebesar 0,629 yang mana lebih besar dari 0,05. Hal ini menunjukkan bahwa CR berpengaruh negatif dan tidak signifikan terhadap Return Saham.

Investor sering beranggapan bahwa CR yang rendah biasanya dianggap menunjukkan masalah dalam likuiditas dan merupakan indikator awal mengenai ketidakmampuan perusahaan dalam memenuhi kewajiban jangka pendeknya. CR yang rendah biasanya dianggap menunjukkan masalah dalam likuiditas dan merupakan indikator awal mengenai ketidakmampuan perusahaan dalam memenuhi kewajiban jangka pendeknya. Para investor sering beranggapan bahwa CR yang tinggi berarti memiliki likuiditas 


\section{JURNAL NOMINAL / VOLUME VII NOMOR 2 / TAHUN 2018}

yang tinggi juga. Namun, dengan likuiditas yang tinggi perusahaan belum tentu mampu dalam mengelola money to create money. Ketidakmampuan perusahaan dalam mengelola money to create money tersebut pada akhirnya dapat mengurangi kemampulabaan perusahaan yang berdampak pada penurunan Return Saham yang akan diterima oleh investor.

g. Pengujian Hipotesis Ketujuh

Ringkasan uji hipotesis ketujuh dapat dilihat pada tabel berikut.

Tabel 12. Hasil Pengujian Hipotesis Ketujuh

\begin{tabular}{ll}
\hline \multicolumn{1}{c}{ Informasi } & Nilai \\
\hline Konstanta & $-0,029$ \\
\hline Koefisien & 0,673 \\
\hline $\mathbf{R}^{\mathbf{2}}$ & 0,087 \\
\hline $\mathbf{t}_{\text {hitung }}$ & 3,559 \\
\hline $\mathbf{t}_{\text {tabel }}$ & 1,656 \\
\hline Sig. & 0,001
\end{tabular}

Berdasarkan Tabel 12, persamaan regresi linear sederhana dalam uji hipotesis ketujuh adalah sebagai berikut.

RERTUN_SAHAM $=-0,029+0,673$ NPM

Nilai koefisien regresi adalah $-0,029$ dan nilai thitung sebesar 3,559 yang mana lebih besar dari tabel 1,656. Tingkat signifikansi sebesar 0,001 yang mana lebih kecil dari 0,05. Hal ini menunjukkan bahwa NPM berpengaruh positif dan signifikan terhadap Return Saham.

Profitabilitas dapat diukur dengan menggunakan NPM. NPM merupakan rasio profitabilitas yang dapat menentukan kemampuan dari perusahaan Real Estate and Property dalam menghasilkan laba bersih terhadap kegiatan operasinya. Semakin tinggi tingkat profitabilitas yang diproksikan dengan NPM, maka semakin tinggi pula tingkat keuntungan yang diperoleh perusahaan dari penjualan bersihnya sehingga mampu meningkatkan kinerja perusahaan dan membuat permintaan saham dari perusahaan Real Estate and Property menjadi semakin meningkat. Meningkatnya permintaan saham pada perusahaan Real Estate and Property akan menyebabkan harga saham semakin tinggi, sehingga Return Saham industri Real Estate and Property juga semakin meningkat.

h. Pengujian Hipotesis Kedelapan

Ringkasan uji hipotesis kedelapan dapat dilihat pada tabel berikut.

Tabel 13. Hasil Pengujian Hipotesis Kedelapan

\begin{tabular}{lc}
\hline \multicolumn{1}{c}{ Informasi } & Nilai \\
\hline Konstanta & 1,421 \\
\hline Koefisien $\left(\mathbf{X}_{\mathbf{1}}\right)$ & $-0,032$ \\
\hline Koefisien $\left(\mathbf{X}_{\mathbf{2}}\right)$ & $-0,00009$ \\
\hline Koefisien $\left(\mathbf{X}_{\mathbf{3}}\right)$ & $-0,031$ \\
\hline Koefisien $\left(\mathbf{X}_{\mathbf{4}}\right)$ & 0,059 \\
\hline Koefisien $\left(\mathbf{X}_{\mathbf{5}}\right)$ & 3,454 \\
\hline Koefisien $\left(\mathbf{X}_{\mathbf{6}}\right)$ & $-0,009$ \\
\hline Koefisien $\left(\mathbf{X}_{\mathbf{7}}\right)$ & $-0,290$ \\
\hline $\mathbf{R}^{\mathbf{2}}$ & 0,355 \\
\hline $\mathbf{F}_{\text {hitung }}$ & 9,997 \\
\hline $\mathbf{F}_{\text {tabel }}$ & 2,080 \\
\hline Sig. & 0,000
\end{tabular}

Berdasarkan Tabel 13, persamaan regresi linear berganda dalam uji hipotesis kedelapan adalah sebagai berikut. 


\section{JURNAL NOMINAL / VOLUME VII NOMOR 2 / TAHUN 2018}

RERTURN_SAHAM $=1,421-0,032$

INFLASI - 0,00009 NILAI_TUKAR -

0,031 SUKU_BUNGA + 0,059 DER +

3,454 ROA - 0,009 CR - 0,290 NPM

Koefisien determinasi yang

dihasilkan adalah sebesar 0,355 atau 35,5\%.

Nilai tersebut mengindikasikan bahwa 35,5\% variasi Return Saham dipengaruhi oleh Inflasi, Nilai Tukar Rupiah Per Dolar AS, Tingkat Suku Bunga BI, DER, ROA, CR, dan NPM, sedangkan $64,5 \%$ dipengaruhi oleh faktor lain.

Nilai $F_{\text {hitung }}$ adalah sebesar 9,997 yang mana lebih besar dari $F_{\text {tabel }}$ sebesar 2,080. Nilai signifikansi adalah sebesar 0,000 yang mana lebih kecil dari 0,05. Berdasarkan hasil pengujian hipotesis, menunjukkan bahwa Inflasi, Nilai Tukar Rupiah Per Dolar AS, Tingkat Suku Bunga BI, DER, ROA, CR, dan NPM secara simultan memiliki pengaruh yang signifikan terhadap Return Saham.

\section{PENUTUP}

\section{Simpulan}

Berdasarkan hasil penelitian dan pembahasan pada bab sebelumnya, dapat disimpulkan sebagai berikut.

1. Inflasi memiliki pengaruh negatif dan signifikan terhadap Return Saham. Inflasi yang tinggi akan mengakibatkan penurunan harga saham, karena menyebabkan kenaikan harga barang secara umum akibat permintaan untuk memenuhi kebutuhan masyarakat yang semakin tinggi, sehingga biaya produksi semakin tinggi dan dapat memengaruhi tingkat pendapatan atau penjualan.

2. Nilai Tukar Rupiah Per Dolar AS memiliki pengaruh negatif dan signifikan terhadap Return Saham. Melemahnya nilai tukar rupiah terhadap dolar AS akan mempengaruhi kinerja perusahaan Real Estate and Property, sebab banyak perusahaan yang memiliki pinjaman luar negeri dalam bentuk dolar AS untuk membiayai proyek jangka panjang maupun untuk pembelian bangunan.

3. Tingkat Suku Bunga BI memiliki pengaruh negatif dan signifikan terhadap Return Saham. Kenaikan Suku Bunga BI akan meningkatkan beban bunga emiten, sehingga laba perusahaan akan terpangkas. Selain itu, ketika Tingkat Suku Bunga BI tinggi, biaya produksi akan meningkat dan harga produk akan menjadi lebih mahal, sehingga konsumen mungkin akan menunda pembeliannya dan menyimpan dananya di bank. Akibatnya penjualan dan laba perusahaan akan mengalami penurunan sehingga akan menurunkan Return Saham perusahaan tersebut.

4. DER memiliki pengaruh positif dan tidak signifikan terhadap Return Saham. Sesuai dengan teori saham bahwa high risk - high return, dimana risiko dari suatu perusahaan ditandai dengan tingkat DER yang dimilikinya, sehingga 


\section{JURNAL NOMINAL / VOLUME VII NOMOR 2 / TAHUN 2018}

semakin tinggi risiko yang diproksikan dengan DER, maka semakin tinggi pula Return Saham yang akan diterima oleh para investor.

5. ROA memiliki pengaruh positif dan signifikan terhadap Return Saham. Perusahaan dengan ROA yang besar dapat menarik investor untuk menanamkan dananya ke perusahaan tersebut. Hal ini disebabkan ROA yang besar menunjukkan kinerja perusahaan yang semakin baik. Tingkat profitabilitas perusahaan yang baik tentu akan menarik minat investor untuk memiliki saham perusahaan tersebut, karena ROA yang tinggi akan meningkatkan tingkat pengembalian (return) yang dapat dinikmati oleh investor.

6. CR memiliki pengaruh negatif dan tidak signifikan terhadap Return Saham. Investor sering beranggapan bahwa CR yang rendah biasanya dianggap menunjukkan masalah dalam likuiditas dan merupakan indikator awal mengenai ketidakmampuan perusahaan dalam memenuhi kewajiban jangka pendeknya. CR yang tinggi, yang berarti memiliki likuiditas yang tinggi juga, dapat pula menunjukkan bahwa perusahaan kurang mampu mengelola money to create money, yang pada akhirnya mengurangi kemampulabaan perusahaan sehingga menurunkan Return Saham.

7. NPM memiliki pengaruh positif dan signifikan terhadap Return Saham.
Semakin tinggi NPM, maka semakin tinggi pula tingkat keuntungan yang diperoleh perusahaan dari penjualan bersihnya sehingga mampu meningkatkan kinerja perusahaan dan membuat permintaan saham dari perusahaan Real Estate and Property menjadi semakin meningkat. Meningkatnya permintaan saham pada perusahaan Real Estate and Property akan menyebabkan harga saham semakin tinggi, sehingga Return Saham industri Real Estate and Property juga semakin meningkat.

8. Inflasi, Nilai Tukar Rupiah Per Dolar AS, DER, ROA, CR, dan NPM secara simultan memiliki pengaruh yang signifikan terhadap Return Saham industri Real Estate and Property yang terdaftar di Bursa Efek Indonesia (BEI) periode 2012 hingga 2016. Hal tersebut dibuktikan dengan nilai $F_{\text {hitung }}$ lebih besar dari $F_{\text {tabel }}(9,997>2,08)$, dan nilai signifikansi adalah sebesar 0,000, hal tersebut menunjukkan bahwa nilai signifikansi lebih kecil dari nilai signifikansi yang telah ditentukan $(0,000$ $<0,05)$.

\section{Saran}

Berdasarkan hasil penelitian dan keterbatasan penelitian, peneliti dapat memberikan saran sebagai berikut:

1. Bagi Perusahaan

a. Perusahaan diharapkan dapat memberikan informasi keuangan 


\section{JURNAL NOMINAL / VOLUME VII NOMOR 2 / TAHUN 2018}

yang bersifat objektif, relevan, dan dapat diuji keabsahannya sehingga dapat meyakinkan pihak investor untuk pengambilan keputusan dalam berinvestasi di perusahaan tersebut.

b. Perusahaan perlu meningkatkan kinerja agar para investor memiliki ketertarikan untuk berinvestasi di perusahaan tersebut.

2. Bagi Investor

Dalam pengambilan keputusan investasi, tidak hanya memperhatikan rasio keuangan dan faktor ekonomi yang digunakan dalam penelitian ini. Namun, investor perlu memperhatikan rasio keuangan lainnya, pengumuman tentang investasi (seperti ekspansi pabrik dan pengembangan riset), gejolak politik dalam negeri maupun luar negeri yang dapat mempengaruhi pergerakan saham.

3. Bagi Peneliti Selanjutnya

a. Penelitian yang selanjutnya perlu menambahkan rasio keuangan lainnya sebagai variabel independen, karena sangat dimungkinkan rasio keuangan lain yang tidak dimasukkan dalam penelitian ini berpengaruh kuat terhadap Return Saham.

\section{DAFTAR PUSTAKA}

Ang, R. (1997). Buku Pintar Pasar Modal Indonesia. Jakarta: Media Staff.

Djayani, N. (1999). Risiko Investasi pada Saham Properti di Bursa Efek Jakarta. Usahawan, 3, XXVIII Maret.
Fahmi, I. (2011). Analisa Laporan Keuangan. Bandung: Alfabeta.

Hanafi, M. M. (2014). Manajemen Keuangan. (Edisi 1). Yogyakarta: BPFE.

Hardiningsih, P., Suryanto, C. A., \& Chariri A. (2002). Pengaruh Faktor Fundamental dan Risiko Ekonomi Terhadap Return Saham pada Perusahaan di Bursa Efek Jakarta: Studi Kasus Basic Industry and Chemical. Jurnal Strategi Bisnis, 8, 83-98.

Hartono, J. (2014). Teori portofolio dan Analisis Investasi. (Edisi 9). Yogyakarta: BPFE.

Hijriah, A. (2007). Analisis Faktor Fundamental dan Risiko Sistematik terhadap Harga Saham Properti di Bursa Efek Indonesia. Tesis. Universitas Sumatera Utara.

http://bi.go.id

http://finance.yahoo.com

http://idx.co.id

Kasmir. (2016). Analisis Laporan Keuangan. (Edisi 4). Jakarta: Raja Grafindo.

Oktavianti, T. \& Agustia, D. (2012). Influence of the Internal Corporate Governance, Leverage Ratio, and Earnings Managements to the Stock Share Return. Journal of Basic and Applied Scientific Research, 2 (8), 7980-7987.

Prihantini, R. (2009). Analisis Pengaruh Inflasi, Nilai Tukar, ROA, DER, dan CR Terhadap Return Saham (Studi Kasus Saham Industri Real Estate and Property yang Terdaftar di Bursa Efek Indonesia Periode 20032006). Tesis. Universitas Diponegoro Semarang.

Saputra, I G. A. A. \& Dharmadiaksa, I. B. (2016). Pengaruh Tingkat Suku Bunga, Nilai Tukar Rupiah, Leverage, dan Profitabilitas pada Return Saham. E-Jurnal Akuntansi 
Universitas Udayana, 16 (2), 10071033.

Sartono, A. (2010). Manajemen Keuangan Teori dan Aplikasi. (Edisi 4). Yogyakarta: BPFE.

Sawir, A. (2009). Analisa Kinerja Keuangan dan Perencanaan Keuangan Perusahaan. Jakarta: PT Gramedia Pustaka Utama.

Sugiyono. (2013). Metode Penelitian Kuantitatif, Kualitatif, dan $R \& D$. Bandung: Alfabeta.

. (2014). Statistika untuk Penelitian. Bandung: Alfabeta. (2016). Metode Penelitian Kuantitatif, Kualitatif, dan $R \& D$. Bandung: Alfabeta.

Syamsuddin, L. (2009). Manajemen Keuangan Perusahaan. Jakarta: PT Raja Grafindo. 